Original Research

\title{
Complaints in Menopausal Women and Its Correlation with Lifestyle and Stress
}

\author{
Ni Ketut Alit Armini, Lailatun Ni'mah and Baiq Selly Silviani
}

Faculty of Nursing, Universitas Airlangga, Surabaya, Indonesia

\section{ABSTRACT}

Introduction: Every woman will have menopausal experiences at the end of a biological process called menstrual cycles. Several complaints can be aggravated by lifestyle and stress. This study was to analyze the relation of lifestyle and stress levels with a menopausal complaint in women.

Methods: This study was correlational with a cross-sectional approach. The study involved 101 menopausal women lived in a community selected by proportional random sampling. The independent variables were lifestyle and stress levels in menopausal women. The dependent variable was a menopausal complaint. This study used primary data provided by questionnaires and interviews. The data were analyzed using Spearman's Rho.

Results: There was strong correlation between lifestyle $(p=0.000 ; r=-0.424)$, stress levels ( $p=0.000 ; r=0.535)$, and complaint in a menopausal woman.

Conclusion: A healthy lifestyle, stress-controlled to minimize complaints in menopausal women. Further research is needed on factors that increase stress in postmenopausal women.

\section{ARTICLE HISTORY}

Received: Feb 25, 2018

Accepted: Dec 31, 2018

\section{KEYWORDS}

lifestyle; stress; menopausal; complain; women

\section{CONTACT}

Ni Ketut Alit Armini \nk.alita@fkp.unair.ac.id $\doteq$ Faculty of Nursing, Universitas Airlangga, Surabaya, Indonesia

Cite this as: Armini, N. K. A., Ni'mah, L., \& Silviani, B. S. (2018). Complaints in Menopausal Women and Its Correlation with Lifestyle and Stress. Jurnal Ners, 13(2),184-189. doi:http://dx.doi.org/10.20473/jn.v13i2.7753

\section{INTRODUCTION}

Life expectancy increased from 70.7 years in 2008 to 73.7 years in 2025 (Kemenkes RI, 2016). Women aged 45-55 years are generally going through menopause, which starts when the ovaries begin to reduce the production of estrogen and progesterone (Curran, 2009). Menopausal women will have climacteric complaints such as irritability, fear, anxiety, hot flushes, depression, headache, fatigue, difficulty in concentrating, forgetfulness, lack of energy, weight gain, pain in bones and muscles, obstipation, heart palpitations, impaired libido, tingling, and dizzy eyes (O'Neill \& Eden, 2012). Menopausal women can experience menopause syndrome complaint for 7 years during the menopause transition and 4.5 years during the final menstrual period (Avis et al., 2015).

Lifestyle and modern diet which is today followed the turns are potentially vulnerable to damage the health and cause disease (Stojanovska, Apostolopoulos, Polman, \& Borkoles, 2014). Women entering menopause will be depressed by loss of their role as a woman and having to face old age. Feelings of depression can be caused by physical, emotional, social, economic, or employment factors or circumstances, events, or experiences that are difficult to manage or survive. The prevalence of depression is higher in women than men throughout their reproductive years along with the menopausal transition (Freeman, Sammel, \& Sanders, 2014). Stress affects the functional disorders of organ disorders, and psychological such as anxiety and or depression (Curran, 2009; Hawari, 2016).

Indonesian women experience five major symptoms during the climacteric, which are muscle and joint pain $(77.7 \%)$, fatigue and missing energy $(68.7 \%)$, loss of sexual desire $(61.3 \%)$, wrinkles (60\%), difficulty concentrating, and hot flushes (29.5\%) (Muharam, 2007). Freeman, Sammel, and Sanders (2014) expressed that as many as $80 \%$ of women experience symptoms of hot flashes other and heart palpitations in the moderate to severe category during the menopausal transition. Menopause occurs due to a decrease in estrogen produced by the ovaries. Women are said to have undergone menopause when menstrual periods have stopped for 12 months (Baziad, 2007). Irregular ovarian function and fluctuating levels of estrogen during menopause cause women often to 
experience symptoms called climacteric syndrome. Menopausal symptoms include vasomotor symptoms with symptoms that appear in the form of a feeling of heat with sweating a lot at night (Curran, 2009; Mulyani, 2013). The decline in estrogen also causes a decrease in neurotransmitters in the brain that affect mood so that anxious feelings appear that trigger depression or stress (Proverawati \& Sulistyawati, 2010).

How that can be done in reducing menopausal complaints such as creating a healthy lifestyle (Moon, Hunter, Moss-Morris, \& Hughes, 2017). It is important for menopausal women to follow a healthy lifestyle in order to have an impact on the psychological effects (Dorjgochoo, 2008). Mansikkamaki et al. (2015) stated that women who carry out physical activities have a better perception of their own health, and better health and global Quality of Life (QoL) compared to women who do not engage in physical activity. One of the ways to reduce menopausal complaints is to create a healthy lifestyle (Priyoto, 2014). The importance of living a healthy lifestyle is that it can also have an impact on the psychology of menopausal women (Rahmayani, Wijaksono, \& Putri, 2016). The aim of this study was to describe the relationship between lifestyle, stress levels, and complaints in menopausal women.

\section{MATERIALS AND METHODS}

The research was a correlational study with a crosssectional design. The population in this study were menopausal women aged 48-60 years in a community health center in Surabaya. The sampling technique used proportional random sampling. Samples were obtained by calculating the proportion of menopausal women in four community health services (posyandu) for elderly in Surabaya. The sample size was 101 women who experienced menopause and live with their husbands. The independent variable in this study is lifestyle and stress levels. The dependent variable in this study is a menopause complaint.

The data were collected using questionnaires in which the researchers interviewedthe respondents through the list of questions. The instrument used to measure menopausal complaints originates from the Menopause Rating Scale (MRS) developed by The Berlin Center for Epidemiology and Health Research so that the questions have been validated in content. The measuring instrument used in this study has been standardized based on the literature so that it does not need to be tested for validity and reliability (Heinemann et al., 2014; Heinemann, Potthoff, \& Schneider, 2003). The MRS questionnaire consists of 5 choices: 0: none; 1 : mild; 2: moderate; 3 : severe; and 4: verheavy. The scale of this instrument can measure three groups of complaints. Psychological complaints are in the form of heart palpitations, feelings of tension or pressure, difficulty sleeping, easy contact, easy panic, difficulty concentrating, and being easily tired. The categories for psychological complaints are 0-1: none; 2-3: mild; 4-6: moderate; $\geq 7$ : severe. Somatic complaints are in the form of feeling dizzy, the body feeling depressed, part of the body feeling pierced by thorns, headaches, and muscle or joint aches. The categories for somatic complaints are 0-2: none; 3-4: mild, 5-8: moderate; $\geq 9$ : severe. Vasomotor complaints are in the form of hot flushes and night sweats. The categories for vasomotor complaints are 0 : none; 1 : mild; 2-3: moderate; 4: severe.

Stress level data used a modified questionnaire from DASS 42 (Lovibond \& Lovibond, 1995) by choosing specific points to assess stress levels, consisting of 4 choices where 0 : none; 1 : sometimes; 2: often; and 3: always with 0-14 rating categories: normal; 15-18: light; 19-25: moderate; 26-33: severe; $\geq 34$ : very severe. Lifestyle data consists of 4 component statements, namely diet, activity/exercise, sleep rest and smoking. There is a positive statement by way of valuation in the form of 4 = always; 3 = often; 2 = sometimes; 1 = never, and on negative statements the method of evaluation is 1 = always; 2 = often; 3 = sometimes; 4 = never, with 21-50 category = unhealthy; $51-80=$ healthy.

Considering the data collection practices of research ethics, the study was approved by the Ethics Committee of Health Research, Nursing Faculty, Universitas Airlangga, with certificate number 590-KEPK on December 4th 2017.

\section{RESULTS}

Most respondents were aged 55-60 years, and there were as many as 61 respondents (60.4\%). Most of the respondents are housewives, as many as 85 respondents (84.2\%). The most of respondents had experienced menopause for 1-5 years as many as 47 respondents (Table 1 )

The majority of respondents had menopausal complaints in moderate category as many as 53 respondents (52.5\%). Most respondents live a healthy lifestyle, as many as 69 respondents (68.3\%), while the level of stress experienced by respondents was mostly in the normal category, as many as 64 respondents (63.4\%) (Table 2).

Most respondents with a healthy lifestyle experienced menopausal complaints within the moderate category, that was 39 respondents (38.6\%), and at least category of such respondents were in normal category as many as five respondents. Most respondents who lived an unhealthy lifestyle experienced menopausal complaints within the severe category, as many as 17 respondents (16.8\%), and no respondents had complaints of menopause in the mild category (Table 3).

Statistical test results using Spearman obtained significance level of $p=0.000$ by assigning degrees of significance $\alpha \leq 0.05$, which means that there is a relationship between lifestyle with complaints of menopausal women. The correlation coefficient was obtained -0.424 , which means that the more healthy 
Table 1. Characteristics of Respondents $(n=101)$

\begin{tabular}{lcc}
\hline \multicolumn{1}{c}{ Characteristics } & $\mathbf{n}$ & $\mathbf{\%}$ \\
\hline Age & & \\
48-54 years & 40 & 39.6 \\
55-60 years & 61 & 60.4 \\
Employment & & \\
Housewife & 85 & 84.2 \\
Private & 8 & 7.9 \\
Self-employed & 8 & 7.9 \\
Menopause experience & & \\
1-5 years & 47 & 46.5 \\
6-10 years & 37 & 36.6 \\
11-15 years & 13 & 12.9 \\
16-20 years & 3 & 3.0 \\
21-25 years & 1 & 1.0 \\
\hline
\end{tabular}

Table 2. Lifestyle, Stress Levels, and Complaints in Menopausal Women $(\mathrm{n}=101)$

\begin{tabular}{lcc}
\hline \multicolumn{1}{c}{ Variables } & $\mathbf{n}$ & $\mathbf{\%}$ \\
\hline Lifestyle & & \\
$\quad$ Healthy & 69 & 68.3 \\
$\quad$ Unhealthy & 32 & 31.7 \\
Stress level & & \\
$\quad$ Normal & 64 & 63.4 \\
$\quad$ Mild & 14 & 13.9 \\
$\quad$ Moderate & 19 & 18.8 \\
$\quad$ Severe & 4 & 4.0 \\
Menopause complaints & & \\
$\quad$ None & 6 & 5.9 \\
$\quad$ Mild & 17 & 16.8 \\
$\quad$ Moderate & 53 & 52.5 \\
$\quad$ Severe & 25 & 24.8 \\
\hline
\end{tabular}

lifestyle will lead to less menopausal complaints (Table 3).

A respondent who was at normal stress level was more likely to experience menopausal complaints in the moderate category, as many as 36 respondents (35.6\%), and six respondents (5.9\%) in the category had severe complaints. Most respondents who are at mild stress level had complaints of menopause in the middle category, as many as nine respondents (9\%). Most respondents who were at moderate stress level experienced the severe category of complaints as many as 14 respondents (14\%), and respondents who were at severe stress level have complaints of menopause in severe categories, as many as three respondents (3\%) (Table 4).

Statistical test results using Spearman obtained significance level of $\mathrm{p}=0.000$ with a degree of significance $\alpha \leq 0.05$, which means there is a relationship between stress levels with symptoms in menopausal women. The correlation coefficient was obtained 0.535 , which means that the lower stress level will lead to less menopausal complaints (Table 4).

\section{DISCUSSION}

Lifestyle-related complaints in postmenopausal women at as indicated by the statistical result that the value of $p=0.000$, which means getting healthier lifestyle menopausal women perceived grievance is reduced. In accordance with the study by Moon,
Hunter, Moss-Morris, and Hughes (2017), the symptoms of menopause are influenced by several factors such as lifestyle, social, and psychosocial.

Terauchi et al. (2010) found that sleep problems such as insomnia and difficulty sleeping well experienced by menopausal women with regard to the characteristic of lifestyle.

The results of the study obtained 17 respondents who lead unhealthy lifestyles with severe menopausal complaints. The age of the 17 respondents were mostly in the range of 55-60 years, which is the age to the elderly stage where sleep problems began to be felt. When 17 respondents said sleep less than 8 hours, sleeplessness, like wake up at night and when awakened body feels sore. Most menopause 6-10 years old where according to Avis et al. (2015) stated menopausal women will experience menopausal complaints for 4.5 years after the cessation of menstruation and 7 years old during the long transition to menopause that the complaint is still perceived by the respondents. A total of 15 respondents out of 17 respondents were housewives. Women who worked as housewives did less frequent sports activities independently at home as the majority of respondents stated that housework is also a form of exercise for them.

Some lifestyle patterns that can be seen are diet, exercise, rest and sleep, smoking, and drinking alcohol. Research results obtained showed that respondents who have healthy lifestyles are mostly situated on the pattern of restful sleep respondents who do not take sleeping pills, it is associated with the majority of respondents who experience sleep problems that are in the category of mild to moderate during menopause where sleep problems in future associated with vasomotor menopausal complaints such as hot flushes and night sweating. The results obtained from interviews showed most respondents as housewives spend more time taking care of the house and some are involved in caring for grandchildren. Most respondents said they took a nap for about 1-2 hours and at night began to sleep at 21:00 and woke up at $04.00 \mathrm{am}$, although sometimes they wake up at midnight to urinate.

Menopausal complaints can be aggravated by smoking and drinking alcoholic beverages due to the levels of estrogen and progesterone in menopausal women diminishing. Cochran, Gallicchio, Miller, Zacur, \& Flaws (2008) suggested that women with larger smoking status had complaints of menopause such as hot flushes and there are sleep problems in women smokers where estrogen and progesterone hormone levels are lower. Oi \& Ohi (2012) found that smoking affects the occurrence of menopausal symptoms such as sweating in the night, hot flushes, insomnia, and other physical symptoms of menopause. Smoking is actually lung exposure to combustion products of tobacco, which are toxic. The burning cigarette toxins will be carried by the blood and will cause it to malfunction for reproduction (Hardy, 2000). The attack of hot flushes may be 
Table 3. Lifestyle to Menopausal Complaints $(n=101)$

\begin{tabular}{lccccc}
\hline \multirow{2}{*}{ Lifestyle } & \multicolumn{5}{c}{ Menopausal Complaints } \\
\cline { 2 - 6 } & $\begin{array}{c}\text { None } \\
\mathbf{n}(\%)\end{array}$ & $\begin{array}{c}\text { Mild } \\
\mathbf{n}(\mathbf{\%})\end{array}$ & $\begin{array}{c}\text { Moderate } \\
\mathbf{n}(\%)\end{array}$ & $\begin{array}{c}\text { Severe } \\
\mathbf{n}(\%)\end{array}$ & $\begin{array}{c}\text { Total } \\
\mathbf{n}(\%)\end{array}$ \\
\hline Healthy & $5(4.9)$ & $17(16.8)$ & $39(38.6)$ & $8(7.0)$ & $69(68.3)$ \\
Unhealthy & $1(1.0)$ & $0(0.0)$ & $14(14.0)$ & $17(16.8)$ & $32(31.7)$ \\
Total & $6(5.9)$ & $17(16.8)$ & $53(52.5)$ & $25(24.0)$ & $101(100)$ \\
& & Spearman's Rho test: $\mathbf{p = 0 . 0 0 0 ; ~ r = - 0 . 4 2 4}$ & \\
\hline
\end{tabular}

Table 4. Level of Stress to Menopausal Complaints ( $n=101)$

\begin{tabular}{lccccc}
\hline \multirow{2}{*}{ Level of Stress } & \multicolumn{5}{c}{ Menopausal Complaints } \\
\cline { 2 - 6 } & $\begin{array}{c}\text { None } \\
\mathbf{n}(\%)\end{array}$ & $\begin{array}{c}\text { Mild } \\
\mathbf{n}(\%)\end{array}$ & $\begin{array}{c}\text { Moderate } \\
\mathbf{n}(\%)\end{array}$ & $\begin{array}{c}\text { Severe } \\
\mathbf{n}(\%)\end{array}$ & $\begin{array}{c}\text { Total } \\
\mathbf{n}(\%)\end{array}$ \\
\hline Normal & $6(5.9)$ & $16(15.8)$ & $36(35.6)$ & $6(5.9)$ & $64(63.3)$ \\
Mild & $0(0.0)$ & $1(1.0)$ & $9(9.0)$ & $2(1.9)$ & $12(11.9)$ \\
Moderate & $0(0.0)$ & $2(1.9)$ & $5(4.9)$ & $14(14.0)$ & $21(20.8)$ \\
Severe & $0(0.0)$ & $0(0.0)$ & $1(1.0)$ & $3(3.0)$ & $4(4.0)$ \\
Total & $6(5.9)$ & $19(18.8)$ & $51(50.5)$ & $25(24.7)$ & $101(100)$ \\
& & Spearman's Rho test: $\mathbf{p = 0 . 0 0 0 ; ~ r = 0 . 5 3 5}$ & & \\
\hline
\end{tabular}

increased due to toxic effects contained in the alcohol because alcohol can relax the muscles of blood vessels causing them to dilate and increase blood flow and the risk of a flush (Mulyani, 2013).

The results of this research found that most respondents who do not smoke and consume alcoholic beverages complain of hot flushes that are in the lightweight category did not even complain of hot flushes. Complaints to do with sleep problems in this study are located mainly in the lightweight category. It also deals with the majority of respondents are Moslem, but the majority of respondents said that smoking is the husband and/or children, where the chances of exposure to cigarette smoke and this may also affect the health of postmenopausal women. It is highly recommended that women who smoke should stop during menopause to reduce the occurrence of an increased likelihood of experiencing complaints such as hot flushes and insomnia. Menopausal women who do not smoke but are in the neighborhood of those who do are advised to avoid smoke.

Physical activity is usually done by most respondents in the form of gymnastics, which are held once a week in posyandu, and doing daily homework independently. Some respondents did not follow gymnastics for reasons to sell. Less healthy lifestyles do most respondents is the lack of exercise habits, associated with discomfort in the joints and sexual problems.

Physical activity has benefits that can reduce a variety of complaints during menopause occurring as well as improving blood circulation, counteracting depression, making you sleep better, and increasing bone density in postmenopausal women. Regular exercise of at least 30 minutes a day can increase life expectancy and improve overall health (Mulyani, 2013; Stojanovska et al., 2014). Sternfeld et al. (2014) explained that physical activity in postmenopausal women did not significantly decrease vasomotor symptoms but can improve overall health and well-being feeling, and sleep quality, and reduce symptoms of insomnia and depression.

Diet is associated with a person's lifestyle. A balanced diet is foods that contain nutrients in the type and amount the body needs. Most respondents have a balanced diet, such as eating foods containing carbohydrates, fat, protein, and vitamins, and eat regularly three times a day a portion that is not excessive. In the results of the interviews, most of the respondents said that the diet commonly consumed is rice, tofu, tempeh, vegetables, eggs, and chicken. Usually, respondents consumed fruit two to three times a week and rarely drink milk. The decline in estrogen and progesterone hormone levels affects the bad mood. It is important to consume foods that provide essential nutrients for healthy brain function. Protein-containing foods may reduce the occurrence of complaints such as hot flushes and improve memory in menopausal women. Estrogen is involved in memory function, while in menopause, the hormone estrogen is decreased, so women who consume protein will help in boosting the release of neurotransmitters that serve to convey the information in the brain and other body parts (Mulyani, 2013). Consuming fruits and vegetables is good for maintaining a healthy body because they contain vitamins, minerals, beta-carotene, and antioxidants that are important for the body (Bauld \& Brown, 2009; Gayatri, 2011). Foods containing vitamin E may help reduce the complaints of hot flushes and vaginal dryness problems (Muharam, 2007; Mulyani, 2013). Most of the respondents already have the habit of eating vegetables, but rarely eat fruits. In research by (Anggrahini \& Handayani, 2014), menopausal women who consumed milk (soymilk) showed a decrease in menopausal complaints because the milk helps in 
supplying the hormone estrogen, the lack of which is caused by decreased ovarian function.

Stress is an adaptive response through individual characteristics or psychological processes directly to the action, situation, and external events that give rise to the special demands of both physical and psychological issues question (Hawari, 2016). Stress is not only about dysfunction or abnormalities of organs, but it also has a psychological impact, for example anxiety and/or depression (Yusuf, Armini, \& Hardiyan, 2008). Severe levels of stress can affect the cardiovascular system, causing symptoms such as heart palpitations, and blood vessel dilation or constriction; other than that the body feels hot flushes that aggravate the symptoms of hot flushes (Bauld \& Brown, 2009). Somatic symptoms are often seen as a symptom of follow up or a result of stress, anxiety, and depression is prolonged. Someone in the field of sexual excitement can also be affected by stress (Thurston \& Joffe, 2011).

People who are stressed often complain of muscle sensations like tingling, aching, and strain. Bone joint complaints are often experienced by, for example, feeling pain or stiffness when moving the limbs. Decreased libido is also often experienced by someone with high stress (Hawari, 2016). The results showed postmenopausal women with stress level category of moderate to severe respiratory symptoms sexual problems weight category. Respondents who had complaints of discomfort in the joints and muscles are located mainly in the category of mild to severe with normal stress levels; the more severe a person's stress level, grievance felt increasingly severe menopause. The majority of respondents said that the way to overcome the stress experienced was by worshiping, praying, and recreation with family. Almost all respondents are housewives, where the frequency of socializing with neighbors and family is more flexible to follow the teaching activities and exercises organized by the posyandu. Bauld \& Brown (2009) and Moon et al. (2017) reported that negative events or emotions can worsen the symptoms of menopause, which demonstrates the importance of the effect of psychosocial factors on menopausal symptoms.

There are three respondents who have highstress levels with severe menopausal complaints, seen from three respondents who have experienced menopause for 5-10 years. This is because the old woman with 7 years of experience of menopausal symptoms during the menopausal transition and 4.5 years after the cessation of menstruation, so the complaint can still be perceived by the respondents with a range of menopause 5-10 years old and is augmented with severe stress levels. All three respondents are housewives whose activities are mostly done at home, are likely to experience higher stress associated with marital problems, and rarely do sports with the family. There was one respondent to the level of stress but had complaints of menopause medium category. Of respondents 60 years of age, at the age of postmenopausal women age limit towards medium.

\section{CONCLUSION}

Menopausal women with healthy lifestyleare more likely to have less menopausal complaints. Menopausal women with lower stress levels experience reduction in menopausal complaints. Respondents manage the stressors by peer socialization, recreation with family, and following health education. Women in pre-menopause period should have motivation to maintain a healthy lifestyle, which involves a balanced diet, physical activity, restful sleep, avoiding smoking and drinking alcoholic beverages, and being able to manage stress in a positive direction to reduce menopausal complaints. Further research can be developed for intervention models to improve healthy lifestyles and stress management in menopausal women.

\section{REFERENCES}

Anggrahini, K., \& Handayani, S. (2014). Pengaruh Konsumsi Susu Kedelai Terhadap Keluhan Menopause. Jurnal Kebidanan, VI(02).

Avis, N. E., Crawford, S. L., Greendale, G., Bromberger, J. T., Everson-Rose, S. A., Gold, E. B., ... Thurston, R. C. (2015). Duration of Menopausal Vasomotor Symptoms Over the Menopause Transition. JAMA Intern Med, 175(4), 531-539.

Bauld, R., \& Brown, R. F. (2009). Stress, Psychological Distress, Psychosocial Factors, Menopause Symptoms And Physical Health In Women. Maturitas, 62, 160-165.

Baziad, A. (2007). Pra, Peri dan Pasca Menopause. (Satgas Endokrinologi Reproduksi, Ed.). Jakarta: Perkumpulan Obstetri dan Ginekologi Indonesia.

Cochran, C. J., Gallicchio, L., Miller, S. R., Zacur, H., \& Flaws, J. A. (2008). Cigarette smoking, androgen levels, and hot flushes in midlife women. Obstet Gynecol, 112, 1037-1044.

Curran, D. (2009). Menopause (Health Sys). Ann Arbor USA: University of Michigan.

Dorjgochoo, T. (2008). Dietary and Lifestyle Predictors of Age at Natural Menopausal and Reproductive Span in The Shanghai Women's Health Study. Menopausal, 15(5), 925-933.

Freeman, E. W., Sammel, M. D., \& Sanders, R. J. (2014). Risk of Long Term Hot Flashes After Natural Menopause: Evidence from the Penn Ovarian Aging Cohort. Menopause, 21(9), 924932.

Gayatri. (2011). Women's Guide. Jakarta: Gagas Media.

Hardy, R. (2000). Smoking, Body Mass Index, Socioeconomic Status and The Menopausal Transition in a British National Cohort. International Journal Epidemiol, 29(5), 845-851.

Hawari, D. (2016). Manajemen Stres, Cemas dan Depresi. Jakarta: FKUI.

Heinemann, K., Ruebig, A., Potthoff, P., Schneider, H. 
P., Strelow, F., Heinemann, L. A., \& Thai, D. M. (2014). The Menopause Rating Scale (MRS) scale: A methodological review. Health and Quality Life Outcome, 2(45).

Heinemann, L. A. J., Potthoff, P., \& Schneider, H. P. G. (2003). International Version of The Menopause Rating Scale (MRS). Health and Quality Life Outcome.

Kemenkes RI. (2016). Situasi Lanjut Usia (Lansia) di Indonesia. Jakarta.

Lovibond, S. H., \& Lovibond, P. F. (1995). Manual for the Depression Anxiety Stress Scales (2nd ed.). Sydney: Sydney: Psychology Foundation.

Mansikkamaki, K., Raitanen, J., Malila, N., Sarkeala, T., Mannisto, Fredman, J., ... Luoto, R. (2015). Physical Activity and Menopause-Related Quality Of Life - A Population-Based Cross-Sectional Study. Maturitas, 80, 69-74.

Moon, Z., Hunter, M. S., Moss-Morris, R., \& Hughes, L. D. (2017). Factors Related To The Experience Of Menopausal Symptoms In Women Prescribed Tamoxifen, Journal of Psychosomatic Obstetrics \& Gynecology. Journal of Psychosomatic Obstetrics \& Gynecology, 38(3), 226-235.

Muharam. (2007). Simposium Nasional Perkumpulan Menopause Indonesia (PERMI) (p. 21-22 April 2007). Jakarta.

Mulyani, N. S. (2013). Menopause: Akhir Siklus Pada Wanita Di Usia Pertengahan. Yogyakarta: Nuha Medika.

O'Neill, S., \& Eden, J. (2012). The pathophysiology of menopausal symptoms. Journal Obstetrics Gynaecology and Reproductive Medicine, 22(3), 63-69.

Oi, N., \& Ohi, K. (2012). A Study Of Menopausal
Symptoms In Relation To Habits Of Smoking And Make-Up Using In Japanese Women Aged 35-59. International Journal of Cosmetic Science, 34, 332-337.

Priyoto. (2014). Teori Sikap dan Perilaku dalam Kesehatan. Yogyakarta: Nuha Medika.

Proveraati, A., \& Sulistyawati, E. (2010). Menopause dan Sindrom Premenopause. Yogyakarta: Nuha Medika.

Rahmayani, D., Wijaksono, M. A., \& Putri, R. R. (2016). Hubungan Tingkat Stress dan Gaya Hidup dengan Kualitas Tidur Lansia si Panti Sosial Tresna Werdha (PSTW) Budi Sejahtera Banjarbaru. Dinamika Kesehatan, 7(1), 113-126.

Sternfeld, B., Guthrie, K. A., Ensrud, K. E., LaCroix, A. Z., Larson, J. C., \& Dunn, A. L. (2014). Efficacy Of Exercise For Menopausal Symptoms: A Randomized Controlled Trial. Menopause, 21, 330-338.

Stojanvska, L., Apostolopoulos, V., Polman, R., \& Borkoles, E. (2014). To Exercise, or, Not to Exercise, During Menopause and Beyond. Maturitas, 77, 318-323.

Terachi, M., Obayashi, S., Akiyoshi, M., Kato, K., Matsushima, E., \& Kubota, T. (2010). Insomnia in Japanese Peri- and Postmenopausal Women. Climacteric, 13, 479-496.

Thurston, R. C., \& Joffe, H. (2011). Vasomotor Symptoms and Menopause: Findings from the Study of Women's Health Across the Nation. Obstet Gynecol Clin North Am, 38(3), 489-501.

Yusuf, A., Armini, N. K. A., \& Hardiyan, D. (2008). Peer Group Support Menurunkan Tingkat Depresi Wanita Menopause, Jurnal Ners Unair. Jurnal Ners, 3(1), 61-66. 